\title{
Study of anthropometric profile of working (labour) adolescent girls of urban slums of India
}

\author{
Yadav S. ${ }^{1}$, Bharti R. ${ }^{2}$ \\ ${ }^{1}$ Dr. Swati Yadav, Assistant Professor, Department of Pediatrics, Chhattisgarh Institute of Medical Sciences, Bilaspur, \\ Chhattisgarh, India, ${ }^{2}$ Dr. Rajesh Bharti, Consultant Psychiatrist, Department of Psychiatry, Sadar Hospital, Purnea, Bihar, \\ India
}

Corresponding Author: Dr. Swati Yadav, Assistant Professor, Department of Pediatrics, Chhattisgarh Institute of Medical Sciences, Bilaspur, Chhattisgarh, India. E-mail: yadavswati93@yahoo.com

\begin{abstract}
Introduction: Adolescence is often described as a phase of life that begins in biology and ends in society. Adolescence is the developmental phase between childhood and adulthood with specific psychological attributes. In India, the adolescent population constitute $22.8 \%$ of the total population. There are around 239 million adolescents in India in the age group of 10-19 years presently. Our aim is to assess the anthropometric profile of working adolescent girls of slum area. Method: Anthropometric data were collected using predesigned proforma of 696 working adolescent girls aged 10-19years by door to door survey in three randomly selected slums of Bilaspur, Chhattisgarh, India. The height, weight and body mass index of the working adolescent were compared with NCHS and Indian reference populations. Result: Analysis of the cases revealed that the maximum number (45.40\%) of adolescents were in 10-13years age group and minimum (27.01\%) were in 17-19 years age group. In 14-16years $27.58 \%$ girls. The difference of mean weight of present study with NCHS standard $50^{\text {th }}$ percentile of weight in various age group ranges from 11.16 to $18.5 \mathrm{kgs}$. Height of all the girls were below $50^{\text {th }}$ percentile. Difference of present study's mean height and NCHS $50^{\text {th }}$ percentile in different age group ranges from $11.7 \mathrm{cms}$ to $20.8 \mathrm{cms}$, the average body mass index was below 15 in 10-12 years age group but was above 15 in 13-19 years age group. Difference of mean BMI of present study with NCHS Standard for different age group ranges from2.15 to 3.57. Discussion: The anthropometric height, weight and BMI data of working adolescent of slum area were lower than Indian as well as NCHS standards. All the girls in the present study had weight and height less than $50^{\text {th }}$ percentile of the National Center for Health Statistics (NCHS), Department of Health, Education and Welfare (DHEW), U.S.A. Standards.
\end{abstract}

Key words: Anthropometric, NCHS, BMI data

\section{Introduction}

Adolescence is often described as a phase of life that begins in biology and ends in society. Adolescence is the developmental phase between childhood and adulthood with specific psychological attributes [1]. Adolescence starts with a period of very rapid physical growth accompanied by the gradual development reproductive organs, secondary sex characteristics and menarche in girl. Not only will they soon bear the future generation they are also the breeding ground for new ideas, languages, values and careers [2]. In India, the adolescent population constitute $22.8 \%$ of the total population. There are around 239 million adolescents in

Manuscript received: $10^{\text {th }}$ August 2019

Reviewed: $20^{\text {th }}$ August 2019

Author Corrected: $27^{\text {th }}$ August 2019

Accepted for Publication: $31^{\text {st }}$ August 2019
India in the age group of 10-19 years presently. Over the next two decades the number of adolescents is likely to increase further but their share to population will decrease marginally as per the projections [3]. WHO described the adolescence as the period of sexual development from the initial appearance of secondary sex characteristics to sexual maturity, psychological development from child to adult identification, and socioeconomic development from dependence to relative independence [4].

In India, $28 \%$ of the total population was living in urban areas in 2001 , with future projection of about $50 \%$, with 605-618 million by 2021-2025. Demographic trends show that while urban average growth rate stabilized at 


\section{Original Research Article}

$3 \%$ over past decade (1991-2001), the slum growth rate was doubled at 5-6\% [5]. Urban adolescents from lower class have to struggle for survival and grow in impoverished, disadvantaged environment making them vulnerable to several risks, malnutrition, risk of poor health, becoming victim of antisocial activities brewing and sale of illicit liquor/sex exploitation/prostitution and drug peddling were reported threats for adolescents from slums in multi indicator survey [6].

\section{Aims and Objectives}

To study the anthropometric profile including weight, height and body mass index of working adolescent girls between 10-19 years of age of urban slum area of Bilaspur (C.G)

\section{Material and Methods}

The Study is mainly focusing on health status of working adolescent girls in urban slums of Bilaspur (C.G.)

\section{Design of study-Cross Sectional study}

Place of study: Various Urban Slums of Bilaspur city

Duration of study: September 2010-July 2011

Selection of slum: Out of 167 slums of Bilaspur city, 3 slums were chosen for study purpose by systematic random sampling with the help of table of random number.

Sample size-The approach adopted for this communitybased study was cross sectional type. Sample size is based on the extent of malnutrition in adolescent. As per literature the problem of malnutrition in school children in India ranged from $10.0-98 \%$ and taking the middle course a prevalence rate of $50 \%$ is assumed. By taking this prevalence and permissible level of error at $10 \%$ sample size is computed as 696 .

Inclusion criteria-All working adolescent females of Slum Area between 10-19 years.

Exclusion criteria-Non-working adolescent female -Females having any major systemic illness, major surgery

Method of data collection- With the help of local health worker a cross sectional survey was done by door to door visit. Examination conducted at local Anganbadi Centre. Data was collected on predesigned pro forma with the answer to questionnaire regarding various aspects like age, sex, religion, address, mother, father, occupation. It is followed by detailed general examination regarding state of health and later complete systemic examination was done. Anthropometric measurement, general physical was recorded on predesigned pro forma. Consent from their selves in those who are above 18 years and from parents in case of minor.

For evaluation of nutritional status of adolescents, anthropometric measurements like weight, height recorded for each adolescent.

Age- Age of each child was calculated to nearest 6 month (e.g.-10 years 4 month and 11 years 8 month as 12 years). Age of most of the children were calculated and cross checked with reference to the events such as some important festival, storm, flood etc. The age was recorded in complete years.

Weight- A bathroom scale was used. It was caliberated against known weight regularly. Zero error was checked for and removed if present every day, with a standard minimal clothing and without shoes. Weight was recorded to nearest 500 gms.

Height- Height in cms was marked on a wall with the help of a measuring tape. All children were measured against the wall. The children were asked to remove the footwear and stand with heels together and head positioned so that the line of vision was perpendicular to the body. A glass scale was brought down to the topmost point on the head, Height was recorded to the nearest $1 \mathrm{~cm}$.

After taking the various measurements, average mean was obtained and standard variation calculated. The result obtained in various age group was compared with international standards-National Center for Health Statistics (NCHS) and other workers reported in literatures.

Body Mass Index: BMI was calculated from measured height and weight of various age to assess the nutritional status. BMI of 15 or below was considered specific indicator to assess under nutrition and give earliest indication of malnutrition

Analysis of data- The data collected from the various aspect in present study was analyzed. The results are tabulated and data also subjected to necessary statistical test whenever required. For statistical analysis Chisquare, Student T test, one-way ANOVA was applied 


\section{Result}

For study purpose girls were divided into early (10-13years), mid (14-16 years) and late (17-19 years) adolescent. Analysis of the cases revealed (Table-1) that the maximum number (45.40\%) of adolescents were in 10-13 years age group and minimum (27.01\%) were in $17-19$ years age group. In $14-16$ years $27.58 \%$ girls.

All the girls in the present study had weight and height less than $50^{\text {th }}$ percentile of the National Center for Health Statistics (NCHS), Department of Health, Education and Welfare (DHEW), U.S.A. Standards (Table-2 and 3).

The difference of mean weight of present study with NCHS standard $50^{\text {th }}$ percentile of weight in various age group ranges from 11.16 to $18.5 \mathrm{kgs}$ (Table-2).

When present study was compared with the anthropometric data of study conducted by Agrawal DK et al $(1992)[7,8]$, they were coming below $50^{\text {th }}$ percentile.

The average body mass index (Table-3) was below 15 in 10-12 years age group but was above 15 in 13-19 years age group.

In Present study BMI of girls were below $50^{\text {th }}$ percentile of NCHS standard, difference of mean BMI of present study with NCHS Standard for different age group ranges from 2.15 to 3.57 .

Table-1: Age wise distribution.

\begin{tabular}{|c|c|}
\hline Age group & Present study \\
\hline $10-13$ & $45.40 \%$ \\
\hline $14-16$ & $27.5 \%$ \\
\hline $17-19$ & $27.01 \%$ \\
\hline
\end{tabular}

Table-2: Age wise distribution of mean weight and range of weight.

\begin{tabular}{|c|c|c|c|}
\hline $\begin{array}{c}\text { Age } \\
(\mathbf{y r s})\end{array}$ & No. of cases & $\begin{array}{c}\text { Weight Range } \\
(\mathbf{k g s})\end{array}$ & $\begin{array}{c}\text { Mean Weight } \\
(\mathbf{k g})\end{array}$ \\
\hline 10 & 86 & $15.2-23.6$ & 21.34 \\
\hline 11 & 56 & $18.6-26.8$ & 22.8 \\
\hline 12 & 94 & $22.3-32.1$ & 26.4 \\
\hline 13 & 80 & $25.1-34.4$ & 28.78 \\
\hline 14 & 64 & $32.4-36.1$ & 33.8 \\
\hline 15 & 76 & $30.8-42.6$ & 35.8 \\
\hline 16 & 52 & $35.4-40.4$ & 37.4 \\
\hline 17 & 72 & $36.2-42.3$ & 39.6 \\
\hline 18 & 52 & $37.8-42.3$ & 40.1 \\
\hline 19 & 64 & $36.4-46.2$ & 42.4 \\
\hline
\end{tabular}


Original Research Article

Table-3: Age wise distribution of mean and range of height and body mass index

\begin{tabular}{|c|c|c|c|c|}
\hline Age & No. of cases & $\begin{array}{c}\text { Range of height } \\
(\mathbf{c m s})\end{array}$ & Mean Height & Body Mass Index \\
\hline 10 & 86 & $120.6-130.2$ & 124.7 & 13.76 \\
\hline 11 & 56 & $120.7-132.4$ & 126.8 & 14.11 \\
\hline 12 & 94 & $129.7-136.1$ & 132.6 & 14.9 \\
\hline 13 & 80 & $131.6-142.1$ & 136.3 & 15.4 \\
\hline 14 & 64 & 136.2144 .3 & 139.6 & 17.2 \\
\hline 15 & 76 & 141.7148 .2 & 144 & 17.2 \\
\hline 16 & 52 & $145.2-152.2$ & 148.7 & 16.88 \\
\hline 17 & 72 & $146.9-152.7$ & 150.2 & 17.5 \\
\hline 18 & 52 & $146.9-154.2$ & 150.6 & 17.63 \\
\hline 19 & 64 & $154.3-146.1$ & 150.5 & 18.6 \\
\hline
\end{tabular}

\section{Discussion}

This study is cross sectional study of anthropometric profile of working adolescent girls of urban slum area. All the girls in the present study were weighing less than $50^{\text {th }}$ percentile of the NCHS Standards. The difference of mean weight of present study with NCHS standard $50^{\text {th }}$ percentile of weight in various age group ranges from 11.16 to $18.5 \mathrm{kgs}$.

Even though all the Indian studies on high socioeconomic group show a higher growth rate as compared to the growth rate of general population of children, the results vary considerably.

When present study was compared with the anthropometric data of study conducted by Agrawal DK et al (1992) [7], they were coming below $50^{\text {th }}$ percentile. The difference of mean weight of present study with $50^{\text {th }}$ percentile mean weight ranges from 5.56 to 10.72 $\mathrm{kgs}$, it may be due to relative improved status of nutrition in the adolescents as Agrawal D K et al (1992) [7, 8] done on affluent society. Singh J et al (2006) [9] and Kaul K K et al (1976) [10] study is more or less similar to present study. Rao $\mathrm{S}$ et al (1998) (11) and Tripathy A M et al (1976) [12] do not corresponds with present study.

In study of Tripathy AM et al (1976) [12]-difference of mean weight with present study's mean weight for different age group ranges from 0.86 to $12.2 \mathrm{kgs}$ and with Rao S et al (1998) [13] study mean weight difference ranges from $0.2 \mathrm{kgs}$ to $6.12 \mathrm{kgs}$.
When height compared with the National Center for Health Statistics (NCHS), Department of Health, Education and Welfare (DHEW), U.S.A. Standards, all girls were below $50^{\text {th }}$ percentile. Difference of present study's mean height and NCHS $50^{\text {th }}$ percentile in different age group ranges from $11.7 \mathrm{cms}$ to $20.8 \mathrm{cms}$, the difference in height is quite obvious as the NCHS standards are the figure of healthy children of highly developed country. The adolescents in present study failed to reach the American Standards because in the present study they belonged to lower socioeconomic group from slums with high prevalence of malnutrition, infection and other morbidities.

When present study is compared with the anthropometric data of study conducted by Agrawal DK et al (1992) [7], they were coming below $50^{\text {th }}$ percentile with difference of mean height in various age group ranging from 6.4 to $15.1 \mathrm{cms}$.

These variation in the results of different workers from the present study may be due to difference in the socioeconomic status, cultural and environmental factors and variation in number of children included in the studies in various samples of different age groups. Study of Singh J et al (2006) [9] is similar to present study but Medhi G et al (2006) [14], Rao S et al (1998) [13], Kaul K K et al (1976) [10] is not similar to present study with range of mean height difference from 0.35 to $7.93 \mathrm{cms}, 0.6$ to $10.0,0.02$ to $10.3 \mathrm{cms}$ respectively. It may be due to the fact that girls in present study are 
Original Research Article

living in slum area which is not properly sanitated, unhygienic, chances of subclinical infections are more. As they are working girls requirement of calories and protein are more but they are consuming lesser calories and protein which is utilized in their work instead of utilization for growth and development.

Body mass index was applied in present study to assess the nutritional status. The body mass index of less than 15 is considered to be the earliest indicator of protein calorie malnutrition. Difference of mean BMI of present study with NCHS Standard for different age group ranges from 2.15 to 3.57 .

The average body mass index was below 15 in 10-12 years age group but was above 15 in 13-19 years age group. Study showed linear increase in BMI with age from 10-13 years age group to 14-16years age group, this gain might be due to attainment of menarche and onset of thelarche and pubarche in these age group.

Divya rani et al (2017) [15] found 60.3\% were under nourished, among them $20.3 \%$ in grade III, $15.1 \%$ in grade II and $24.9 \%$ in grade I under nutrition. In contrast shahid et al [16] found that $20 \%$ of the girls are underweight (BMI <18.5\%),77\% within normal limit, and $3 \%$ were obese

\section{Conclusion}

All the anthropometrics parameter of the adolescents in the present study were less than the International (NCHS) standards and Indian standards. This might be due to the fact that adolescents of NCHS (17) standard and other Indian studies were from affluent families getting better nutrition leading to better growth. Difference with NCHS may be due to racial variation and difference in the environment in which American children are brought up

\section{What the study adds to the existing knowledge?}

As there are only few studies on anthropometric profile of working (labour) adolescent girls of urban slum area, the present study will be helpful in knowing the magnitude of under nutrition in them as well will be helpful in planning and implementation of various program for enhancement of their nutritional status.

Thus, it can be recommended that any attempt for the improvement of nutritional status of slums children must enhanced like rigorous implementation of nutrition programs and child health services, fortification of food items and nutritional education of family.

\section{Author's contribution}

Dr. Rajesh Bharti: Conceived the idea of study, participated in study design, analysis of data and interpretation of results.

Dr. Swati Yadav: Supervised the study, reviewed related literature, data collection and write up of manuscript. All authors have read and approved the final manuscript.

Funding: Nil, Conflict of interest: None initiated, Permission from IRB: Yes

\section{References}

1. UNFPA: Adolescent in India. A profile. December 2003.

2. De Silva WI. Emerging reproduction health issues among adolescent in India. 1998;139.

3. Govt of India: Planning Commission-Report of working group on adolescents for the tenth five year plan. June 2001.

4. De Silva WI. Emerging reproductive health issues among adolescents in Asia. Boston, MA: Harvard School of Public Health. 1998.

5. Agarwal S, Taneja S. All slums are not equal: child health conditions among the urban poor. Indian Pediatrics. 2005;42(3):233-244.

6. UNFPA: Annual Report. December 2003 Available at https://www.unfpa.org/ sites/default/ files/pub-pdf/ annual_report03_eng.pdf.

7. Agarwal DK, Agarwal KN, Upadhyay SK, Mittal R, Prakash R, Rai S. Physical and sexual growth pattern of affluent Indian children from 5 to 18 years of age. Indian Pediat. 1992;29(10):1203-1282.

8. Agarwal KN, Sen S, Tripathi AM, Katiyar GP. Physical growth characteristics in relation to sexual growth. Indian Pediat. 1974;12(2):99-105.

9. Singh J, Singh JV, Srivastava AK. Health status of adolescent girls in slums of Lucknow. Indian J Comm Med. 2006;31(2):102. 
Original Research Article

10. Kual KK, Taskar AD, Madhavan S, Mukerji B, Parekh P, Sawhney K, Goel RK, Lamba IM. Growth in height and weight of urban Madhya Pradesh adolescents. Indian Pediat. 1976;13(1):31-39.

11. Rao S, Joshi S, Kanade A. Height velocity, body fat and menarcheal age of Indian girls. Indian Pediat. 1998;35(7):619-628.

12. Tripathi AM, Agarwal DK, Sen S, Agarwal KN. Physical growth during adolescence in Delhi school children. Indian Pediat. 1976;13(3):191-199.

13. Rao S, Joshi S, Kanade A. Height velocity, body fat and menarcheal age of Indian girls. Indian Pediat. 1998;35(7):619-628.
14. Medhi GK, Hazarika NC, Mahanta J. Nutritional status of adolescents among tea garden workers. The Indian J Pediat. 2007;74(4):343-347.

15. Rani D, Singh JK, Srivastava M, Verma P, Srivastava D, Singh SP. Assessment of nutritional status of teenage adolescent girls in urban slum of Varanasi. International journal of current research and review 2018;10(20):1-10. doi: http/dx.doi.org/10.31782/IJCRR. 2018.10202.

16. Shahid A, Siddiqui FR, Bhatti MA, Ahmed M, Khan MW. Assessment of nutritional status of adolescent college girls at Rawalpindi. Ann King Edward Med Univers. 2009;15(1):11. doi: https://doi. org/10. 21649/akemu.v15i1.24

\section{How to cite this article?}

Yadav S, Bharti R. Study of anthropometric profile of working (labour) adolescent girls of urban slums of India. Int J Pediatr Res. 2019;6(08):418-423.doi:10.17511/ijpr. 2019.i08.05 